\title{
(Educ)AÇÃO Musical Superior no Sudeste do Brasil: Currículo como Prática e Possibilidades de Ações do Pensamento (De)colonialista
}

\author{
Euridiana Silva Souza \\ Universidade Federal de Minas de Gerais/ Fábrica de Artes \\ Belo Horizonte, Brasil
}

O presente texto parte da análise documental do conteúdo dos currículos oficiais e de questionários com egressos de quatro bacharelados em música localizados em instituições de ensino de superior na região sudeste do Brasil. Esta análise propõe uma reflexão sobre a concepção de currículo como prática e as políticas de flexibilização curricular; as visões de música, cultura e sociedade que regem os currículos analisados e como tais visões se relacionam com a compreensão de formação do profissional em música; as realidades e possibilidade de ação do pensamento (de)colonialista apresentadas nas formações curriculares e a agência dos sujeitos que colocam currículo em ação. As reflexões mostram tanto a manutenção dos valores coloniais eurocêntricos na formação dos bacharéis quanto a abertura para outros percursos de formação. Além disto, localiza a educação musical superior como campo de possibilidade para uma ampliação epistêmica, apoiada na flexibilização curricular e nos projetos políticos de expansão universitária, além de tornar-se um campo de ação de profilaxia social.

Palavras-chave: Educação musical superior. Currículo como prática. Colonialismo e decolonialismo. Flexibilização curricular no Brasil. Bacharelados em música

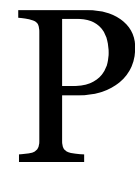

ropor reflexões em (educ)AÇÃO musical superior, parte de uma provocação linguística para revelar a dimensão da ação, da prática e da práxis, nos processos de ensino-aprendizagem na formação superior em música. Tal jogo linguístico toma a educação em sua dimensão "problematizadora", que se faz enquanto "esforço permanente através do qual os homens (sic) vão percebendo, criticamente, como estão sendo no mundo com que e em que se acham" (Freire 2015, 100).

(C) Euridiana Silva Souza. 2019. O conteúdo deste artigo é de total responsabilidade da autora. A ACT Journal e o Grupo Mayday não são responsáveis por quaisquer ações legais que possam surgir do conteúdo deste artigo, incluindo, mas não limitado a infrações de direitos autorais. 
As problematizações que aqui se apresentam partem da consciência de que as músicas, como fazeres sociais e relacionais, ocupam quaisquer espaços em uma infinidade de práticas e concepções. No entanto, como objeto legitimado de estudo nas instituições de ensino superior, majoritariamente, se definem sob o peso tradição colonialista eurocêntrica.

A colonialidade, como bem apontam Shifres e Rosabal-Coto (2017), apoiados em Quijano (2000), é uma lógica de pensamento pautada na ontologia do modelo ideal de ser humano da modernidade europeia. Através da colonialidade do saber (Lander 2005) e do poder (Quinjano 2005), esta lógica conquistadora e excludente definiu, e ainda define, quem sabe e quem pode dentro de uma sociedade. "A colonialidade do saber nos revela ... um legado epistemológico do eurocentrismo que nos impede de compreender o mundo a partir do próprio mundo em que vivemos e das epistemes que lhes são próprias" (Porto-Gonçalves 2005, 3).

Em música, e principalmente na educação musical superior brasileira, a colonialidade pode ser presenciada por uma reprodutibilidade do sistema conservatorial europeu, não somente em suas práticas de ensino, mas, especialmente, na definição do objeto a ser ensinado, a música conhecida como música clássica/erudita/concerto. Ideais de música como "objeto elaborado para ser contemplado, distanciado do sujeito que o realiza ou participa de sua construção", são perpetuados através de uma prática que "classifica o que é música e o que não, quem tem a habilidade para ser músico e quem não, determinando papéis hierarquizados para as pessoas participantes nas diferentes experiências musicais-compositor, executante e audiência" (Shifres e Rosabal-Coto 2017, 86). Uma música como objeto/produto em si, cujas relações de ensino-aprendizagem replicam práticas passadas, dificultando não somente a criação de uma identidade própria da música local (Woodford 2002), mas também preservando a manutenção de um habitus conservatorial (Pereira 2013) ${ }^{1}$ que é feito e refeito na sua condição de estrutura estruturante (Bourdieu 2008) do pensamento hegemônico.

Esta hegemonia do pensamento colonial culmina em "estratégias de opressão e silenciamento de vários tipos” (Miglievich-Ribeiro 2014, 67): de ser, de estar, de poder, de existir e conhecer. Tais estratégias anulam a alteridade em nome de uma homogenia ditada hierarquicamente de cima para baixo, de um norte político-econômico a um sul dependente e subalterno (Kummu e Varis 2011; Grosfoguel 2013). O movimento decolonial surge como uma resistência "teórico-prático, político e epistemológico à lógica da modernidade/colonialidade” (Ballestrin 2013, 105).

Euridiana Silva Souza. 2019. (Educ)AÇÃO musical superior no sudeste do Brasil: Currículo como prática e possibilidades de ações do pensamento (de)colonialista. Action, Criticism, and Theory for Music Education 18 (3): 56-84. https://doi.org/10.22176/act18.3.56 
Este movimento oferece uma contraposição à tendência histórica da divisão entre Norte e Sul Global. "Nesse sentido, é revelador que ao esforço de teorização no Brasil e na América Latina caibam os rótulos de 'pensamento' e não 'teoria' social e política” (Ballestrin 2013, 108-9). Este pensamento desnuda as diferenças abissais (Santos 2007) entre as concepções europeias e a práxis latino-americana.

Sob este marco teórico, este texto emerge deum processo de pesquisa em educação comparada que se propõe a refletir as seguintes questões: a) Quais as concepções epistemológicas de fazer musical e de cultura regem os currículos oficiais da educação musical superior no sudeste do Brasil? b) Concebendo o currículo como prática, considerando as confluências múltiplas de saberes musicais, e partindo da existência do pensamento (de)colonialista ${ }^{2}$, quais as possibilidades de ação do currículo, ou, de um currículo em ação, tratando-se de reprodução ou inovação epistêmica?

Este texto está estruturado em quatro partes. A primeira parte apresenta o contexto de pesquisa e a metodologia por trás da reflexão. A segunda parte revisa brevemente a literatura que apresenta a concepção do currículo como prática dialógica entre todos os agentes que compõem o cenário educativo.

Desenvolver esta acepção de currículo como âmbito prático tem o atrativo de poder ordenar em torno deste discurso as funções que cumpre e modo como as realiza, estudando-o processualmente: se expressa numa prática e ganha significado dentro de uma prática.... É o contexto da prática, ao mesmo tempo que é contextualizado por ele (Sacristán 2000, 16).

A terceira parte apresenta as IES selecionadas para o estudo e traz trechos dos seus textos curriculares, compreendidos sob uma perspectiva processual, e analisa concepções epistêmicas sobre música e cultura, que se revelam como escolhas e posicionamentos políticos das instituições e dos sujeitos que a formam.

A quarta parte traz destacada a questão da "formação ampla, crítica e reflexiva”, apontada como meta para os bacharelados em música. O que seria esse amplo, crítico e reflexivo? Que tipo pensamento (de)colonialista pode ser contemplado? Os parênteses aqui são usados como forma de fazer referência às duas possibilidades: 1) da virada para o pensamento decolonial, um pensamento outro e do outro, de outras formas de conhecimento e práticas musicais; 2) da possível, e talvez provável, manutenção da colonialidade. Isto ocorre porque, por um lado, o espaço acadêmico de formação superior estimula a reflexão e a crítica sobre teorias e práticas, mas, por outro, também propicia a manutenção da distinção

Euridiana Silva Souza. 2019. (Educ)AÇÃO musical superior no sudeste do Brasil: Currículo como prática e possibilidades de ações do pensamento (de)colonialista. Action, Criticism, and Theory for Music Education 18 (3): 56-84. https://doi.org/10.22176/act18.3.56 
social do julgamento (Bourdieu 2008) e da diferença colonial, que "no/do mundo colonial/moderno é também o lugar onde se articulou o 'ocidentalismo', como imaginário dominante do mundo colonial moderno (Mignolo 2003, 10).

Na conclusão, professores e alunos são apresentados como sujeitos da prática. O currículo aqui é compreendido como prática de documentos que selecionam e legitimam a forma como as instituições compreendem música e cultura. Mas também é observado em ação, isto é, transcendendo o papel que o acolhe e sendo realizado humanamente, nas relações das salas de aula e da vida. Partindo desta visão, apresento o currículo como ferramenta para ação preventiva no campo social. Um tipo de profilaxia para o bem estar social, que possa dar voz aos silenciados, possibilitando o ouvir das resistências e favorecendo o bem viver (Santos 2004). Um currículo que revele a ação, presente no termo educação, como assunção consciente de escolhas, que revele e possibilite outros projetos de educação musical superior e formação profissional do músico. Afinal, somos construídos não só de raízes europeias, mas de uma multiplicidade de raízes que foram deixadas no limbo. Somos heterogêneos e necessitamos que

todos entendam que a finalidade de um programa de Educação Musical [e de educação musical superior] é muito mais que oferecer uma opção de emprego [e de formação para um emprego] - trata-se de uma opção existencial, de um movimento radical contra a homogeneização, do encaminhamento de uma vida, de uma existência para o questionamento, para a angústia criadora, para o inconformismo, para a possibilidade de transformação, para a valorização da vida de forma intensa e violentamente artística (Czanok 2013).

\section{A região sudeste do Brasil: o contexto e a metodologia do estudo so- bre os bacharelados em música}

A região sudeste do Brasil é composta pelos estados de São Paulo, Rio de Janeiro, Minas Gerais e Espírito Santo. Estes estados concentram os maiores índices demográficos e econômicos do país 3 , o que afeta diretamente as oportunidades de oferta e acesso à educação musical superior, pública e privada. Isto se se comprova pela quantidade de instituições de ensino superior (IES) registradas, maior que a somatória de instituições nas demais regiões do país4. Junta-se a isso o desenvolvimento de mercado de trabalho em música mais expandido, com múltiplas possibilidades e nichos de atuação. As diferenças numéricas da comparação de análises percentuais e estatísticas entre o Sudeste e as demais macrorregiões brasileiras é um dos fatores que respalda a minha escolha por esta região. Ademais, é

Euridiana Silva Souza. 2019. (Educ)AÇÃO musical superior no sudeste do Brasil: Currículo como prática e possibilidades de ações do pensamento (de)colonialista. Action, Criticism, and Theory for Music Education 18 (3): 56-84. https://doi.org/10.22176/act18.3.56 
a região na qual vivo, o que facilita o acesso às realidades mencionadas, que se mostram não somente como dado externo, mas como parte da minha própria vivência enquanto profissional atuante na área da música.

A região sudeste é diversa em fazeres sócio-culturais-musicais, representados na coexistência de povos indígenas 5 (Tugny 2015), comunidades quilombolas ${ }^{6}$ (Dempsey 2017; Lucas 2002), comunidades de diferentes matrizes religiosas (Morais 2018), comunidades das maiores favelas do país (Anacoana 2012), nas quais convivem rap (Garcia 2013), funk (Palombini 2013), samba, rock (Aredes 2015), em suas versões de massa ou em suas versões de menor circulação, que revelam processos de resistência cultural.

Os trabalhos pontuados acima se localizam nos estudos etnomusicológicos e nas aproximações entre música e ciências sociais. Estas áreas têm a alteridade como princípio legitimado, como possibilidade de ser e estar neste mundo. A educação musical, em suas aproximações e diálogos com a etnomusicologia e a sociologia tem voltado seu olhar para a diversidade, para outras possibilidades de ensino-aprendizagem e para uma tomada de consciência do peso da tradição europeia (Arroyo et al. 2003; Fragoso 2018; Green 2014; Nettl 2010). No entanto, como estas concepções de alteridade se apresentam na educação musical superior, no processo de formação profissional dos bacharéis em música?

A necessidade de se questionar os bacharelados dentro do sistema do ensino superior justifica-se pela escassez/ interrupção de estudos que problematizam diretamente os tais cursos em música a partir de sua constituição pedagógica (Louro 1997, 1998; Louro e Souza 1999) ou em suas peculiaridades na dinâmica do ensino superior público no Brasil. Os bacharelados, por excelência, carregam o modelo conservatorial no sistema universitário. Tal modelo traz não somente princípios colonialistas eurocêntricos, mas geram questões controversas na administração dos sistemas de ensino superior7. Urge que estes cursos sejam observados para além das "tradicionais 'estufas' concentradas no treinamento de performers, e desenvolvam um currículo, e uma prática curricular, mais flexível e realística” (Bennett 2008), de modo a atender ao contexto cultural dos alunos.

Euridiana Silva Souza. 2019. (Educ)AÇÃO musical superior no sudeste do Brasil: Currículo como prática e possibilidades de ações do pensamento (de)colonialista. Action, Criticism, and Theory for Music Education 18 (3): 56-84. https://doi.org/10.22176/act18.3.56 


\begin{tabular}{|c|c|c|c|}
\hline \multicolumn{4}{|c|}{ Educação Superior no Brasil } \\
\hline \multicolumn{2}{|c|}{ Quantidade de IES } & IES públicas & IES privadas \\
\hline \multicolumn{2}{|c|}{2407} & 296 & 2111 \\
\hline \multicolumn{4}{|c|}{ Educação Musical Superior no Brasil } \\
\hline \multicolumn{2}{|c|}{$\begin{array}{l}\text { Quantidade de IES que oferecem o curso } \\
\text { superior de Música }\end{array}$} & IES públicas & IES privadas \\
\hline \multicolumn{2}{|c|}{123} & 58 & 65 \\
\hline \multicolumn{4}{|c|}{ Modalidades de cursos oferecidos / quantidade de IES ofertantes } \\
\hline Bacharelado presencial & Bacharelado EAD & Licenciatura presencial & Licenciatura EAD \\
\hline 52 & 1 & 108 & 9 \\
\hline \multicolumn{4}{|c|}{ Bacharelados em Música } \\
\hline \multicolumn{2}{|c|}{$\begin{array}{l}\text { Quantidade de IES que oferecem o curso de } \\
\text { bacharelado em Música }\end{array}$} & IES públicas & IES privadas \\
\hline \multicolumn{2}{|c|}{52} & 31 & 21 \\
\hline
\end{tabular}

Quadro 1: Educação musical superior no Brasil

Fonte: Cruzamento de dados do Censo da Educação Superior (INEP, 2016) e Sistema eMEC.
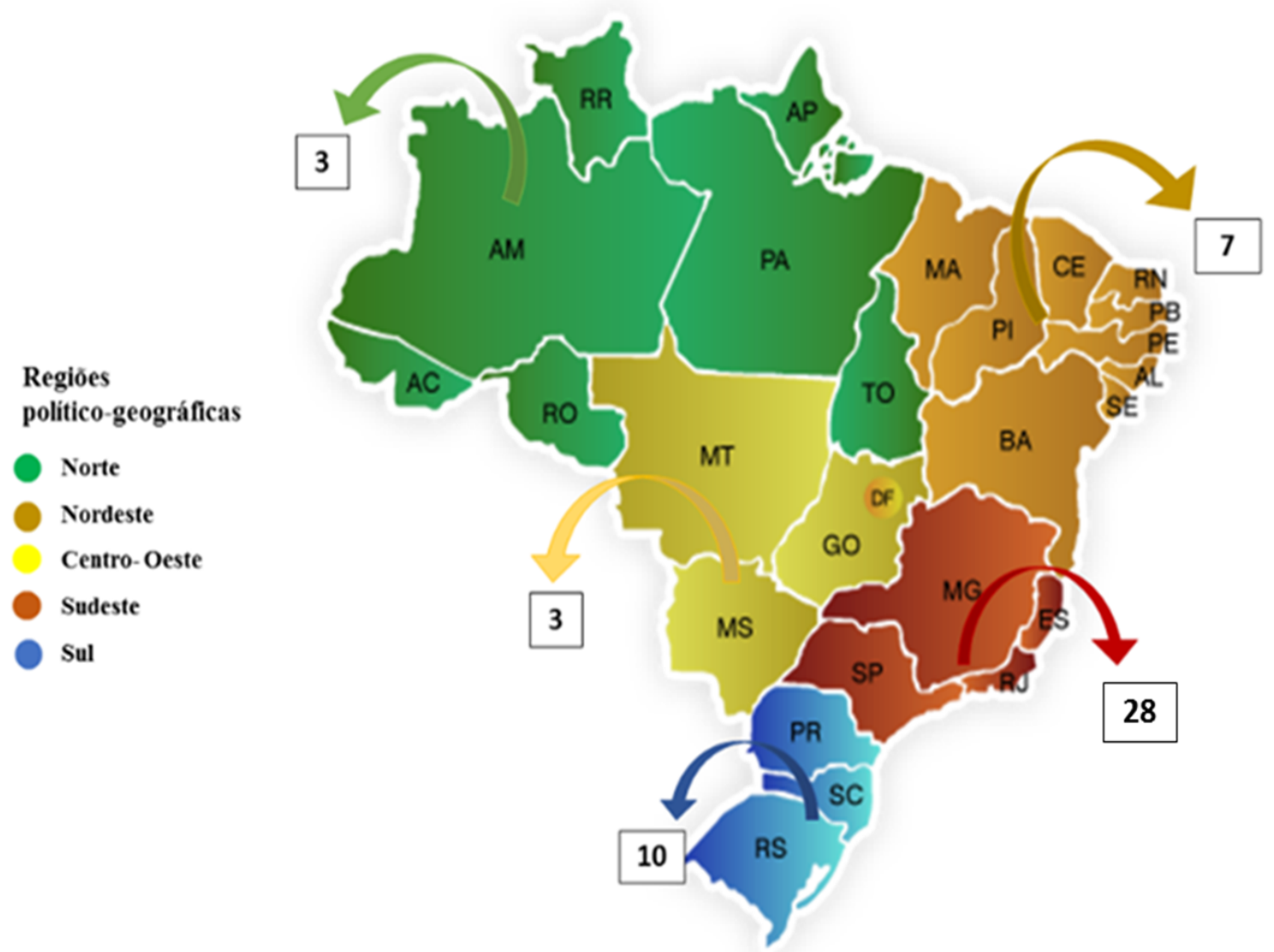

Figura 1: Distribuição dos bacharelados em música no Brasil. Fonte: Sistema e-MEC

Euridiana Silva Souza. 2019. (Educ)AÇÃO musical superior no sudeste do Brasil: Currículo como prática e possibilidades de ações do pensamento (de)colonialista. Action, Criticism, and Theory for Music Education 18 (3): 56-84. https://doi.org/10.22176/act18.3.56 
Para esta reflexão serão apresentados dados colhidos entre os anos de 2016 e 2018, que compõem parte do corpus da minha pesquisa de doutorado ${ }^{8}$. O trabalho se pauta na análise de quatro IES públicas, uma em cada capital da região: Universidade de São Paulo (USP), Universidade Federal do Rio de Janeiro (UFRJ), Universidade Federal de Minas Gerais (UFMG), Faculdade de Música do Espírito Santo (FAMES).

Os documentos para análise foram coletados nos sites das IES-projetos pedagógicos, ementas das disciplinas, grades curriculares9-e em questionários online aplicados à 42 graduados nestas instituições. Os dados apresentados foram analisados segundo seus conteúdos. Após leitura minuciosa dos projetos pedagógicos, seus textos foram agrupados por categorias referentes aos seguintes temas: descrição do objeto de ensino (música); concepção de formação profissional; perfil do egresso; contextualização histórico social do curso/profissão; características de flexibilização/mobilidade curricular. Os quadros curriculares foram analisados e desmembrados segundo as proporções de disciplinas obrigatórias, optativas e outras formas geradoras de crédito. As relações estabelecidas entre os textos dos projetos e os quadros curriculares se deram por aproximação de conteúdo semântico e por ligações mais diretas referentes às áreas disciplinares mais gerais (performance, educação, análise e estruturação musical, história, etc.). Os questionários foram organizados em três grandes temáticas (pré-formação, formação e inserção no mercado de trabalho pós-formação). As respostas foram contabilizadas de forma quantitativa quando a pergunta apresentava opções prévias de resposta (mapeamento percentual); e por análise de agrupamento nas repostas abertas (Hair Jr 2009). As categorias de análise emergiram segundo a repetição de palavras (sinônimos e correlatos), sendo consideradas dentro de um quadro de analítico mais amplo no escopo da pesquisa.

\section{Currículos como documentos de prática}

Parto da definição de currículo "como o projeto seletivo da cultura, cultural, social, política e administrativamente condicionado, que preenche a atividade escolar e que se torna realidade dentro das condições da escola tal como se acha configurada" (Sacristán 2000, 35, itálico do autor). Tal definição traz em si problemáticas e ressalta a não neutralidade das escolhas na construção de textos, grades curriculares e ementas de disciplinas. Uma não neutralidade que se mostra não

Euridiana Silva Souza. 2019. (Educ)AÇÃO musical superior no sudeste do Brasil: Currículo como prática e possibilidades de ações do pensamento (de)colonialista. Action, Criticism, and Theory for Music Education 18 (3): 56-84. https://doi.org/10.22176/act18.3.56 
somente no papel, que tudo aceita, mas na própria atualização e ação do currículo como prática. O currículo não pode considerar uma consciência simplista na qual a vida é "prática", da ordem prático-utilitarista (Sánchez Vásquez 2011). No currículo a práxis é considerada como "fundamento de conhecimento".

Se o homem apenas conhece o mundo na medida em que é objeto ou produto da sua atividade, e se, além disso, apenas o conhece porque atua praticamente, e graças a sua atividade real, transformadora, isso significa que o problema da realidade objetiva ... não é um problema que possa ser resolvido teoricamente, em um mero confronto teórico de nosso conceito com o objeto, ou do meu pensamento com outros pensamentos.... Para mostrar sua verdade há que sair de si mesmo, plasmar-se, ganhar corpo na própria realidade, sob a forma de atividade prática (Sánchez Vásquez 2011, 148).

Estou ciente de que a prática não fala por si. Há que se analisar e interpretar os fatos e fazeres práticos partindo de uma perspectiva teórica em relação à própria prática. Assim, concordo com Sacristán (2000) quando ele pontua três problemáticas na concepção de currículo como prática. A primeira é situada no fato de que a aprendizagem dos alunos é organizada segundo um projeto cultural vigente, através de seleção e codificação singular dos conteúdos tidos como necessários ou pertinentes. A segunda, destaca que o currículo se realiza dentro de determinadas condições políticas, administrativas e institucionais. Estas condições não só plasmam como também trazem em si a dimensão oculta do currículo, dos valores e fazeres que não estão explícitos no texto escrito, mas se manifestam de forma física e conceitual nas instituições de ensino. A terceira destaca o campo social no qual são feitas as escolhas curriculares, para que se cumpra dentro de um campo escolar. Deste campo social são definidas as filosofias curriculares, que sintetizam as posições filosóficas, epistemológicas, científicas, pedagógicas e de valores sociais.

Ao relacionar as três problemáticas à educação musical superior no Brasil pontuo as constatações/reflexões que seguem.

1) O que é necessário e pertinente na educação musical superior no Brasil ainda está arraigado no valor absoluto da música europeia. Segundo Pereira, "o habitus conservatorial acaba por inculcar nos indivíduos uma estética de superioridade da música erudita baseada numa autonomia do contexto social, desconsiderando delineações, e supervalorizando os significados inerentes a serem estudados" (Pereira 2013, 255). Desta forma, a música, compreendida como valor em si, obra de arte legítima, é colocada nos documentos curriculares deslocada de seu contexto de produção e circulação. Os currículos parecem não problematizar "a organização

Euridiana Silva Souza. 2019. (Educ)AÇÃO musical superior no sudeste do Brasil: Currículo como prática e possibilidades de ações do pensamento (de)colonialista. Action, Criticism, and Theory for Music Education 18 (3): 56-84. https://doi.org/10.22176/act18.3.56 
da prática musical, negligenciando processos culturais que produzem significados e influenciam a aproximação entre indivíduos e músicas" (255).

2) As condições políticas na realidade brasileira têm mudado rapidamente, o que revela a falta de políticas de Estado e a fragilidade das políticas de governo. As leis, os regimentos que conduzem a prática das IES, as condições de financiamento do ensino e da pesquisa mudam frequentemente. Das políticas que afetam diretamente os currículos superiores, destaco a flexibilização curricular, que teve suas discussões e implementação no Brasil na década de 1990. Inserida em um movimento de adequação entre a formação universitária e o mercado de trabalho, tal mudança propõem o "ideário da flexibilidade curricular" como possibilidade de "sintonia com a vida e com a empregabilidade" (Catani, Oliveira, e Dourado 2001, 72). Esta alteração curricular permite que os estudantes conduzam suas formações dentro de um quadro de disciplinas obrigatórias e optativas, além de possibilitar, dependendo do projeto curricular adotado por cada instituição, um maior trânsito dos estudantes entre as unidades acadêmicas da universidade. Estes processos multidirecionais de formação assumem diferentes nomenclaturas, mas no geral apontam para formações complementares ou formações livres. Estas formações intentam aumentar os diferentes capitais adquiridos no processo de formação superior, desenvolvendo autonomia e protagonismo dos alunos.

3) Considerando que as políticas curriculares refletem o campo sócio histórico no qual se desenvolvem, os currículos podem mais do que reproduzir valores de outras terras e mentes. Podem (quiçá, devem) se tornar uma prática efetiva de diálogo com a realidade. Devem servir não apenas como conjunto de conhecimentos e técnicas necessárias para a formação musical, mas como atualização no espaçotempo em que é realizado, com a "responsabilidade ética" de carregar também uma concepção de mundo. Podem permitir que os seres que o praticam sejam "condicionados, mas não determinados", reconhecendo que a "história é tempo de possibilidade e não de determinismo" e que presente, e futuro, são "problemáticos e não inexoráveis" (Freire 1996, 21).

Seguindo estas problematizações e cruzando conteúdo e contexto, destaco dois conceitos fundantes nas seleções que definem os currículos superiores em música: música e cultura. Música, como conteúdo e objeto principal do curso; cultura (na sociedade) como contexto no qual se desenvolvem conteúdos e percursos. Após uma breve caracterização das IES selecionadas para este estudo, comparo como

Euridiana Silva Souza. 2019. (Educ)AÇÃO musical superior no sudeste do Brasil: Currículo como prática e possibilidades de ações do pensamento (de)colonialista. Action, Criticism, and Theory for Music Education 18 (3): 56-84. https://doi.org/10.22176/act18.3.56 
estas duas instâncias se enlaçam nas definições do que seja uma boa formação profissional para o músico.

\section{Concepções curriculares de música e cultura em quatro IES do su- deste brasileiro}

Os quadros abaixo apresentam, de forma sucinta, as quatro IES selecionadas para este estudo ${ }^{10}$.

\begin{tabular}{|c|c|}
\hline $\begin{array}{l}\text { IES: Faculdade de Música do Espírito Santo "Maurício de } \\
\text { Oliveira" } \\
\text { Sigla: FAMES } \\
\text { Ano de fundação da IES: } 1952 \\
\text { Ano de fundação do curso: } 1952 \\
\text { Fundado como: Escola de Música do Espírito Santo } \\
\text { Localização: Vitória, ES } \\
\text { Administração: Pública, estadual } \\
\text { Tipo de ingresso: Vestibular próprio + HE (teste de habilidades } \\
\text { específicas) } \\
\text { Vagas de bacharelado ofertadas por ano: } 40 \\
\text { Média de egressos por ano: } 11 \\
\text { Site: http://fames.es.gov.br/ }\end{array}$ & $\begin{array}{l}\text { IES: Universidade Federal de Minas Gerais } \\
\text { Sigla: UFMG } \\
\text { Ano de fundação da IES: } 1927 \\
\text { Ano de fundação do curso: } 1925 \\
\text { Fundado como: Conservatório Mineiro de Música, incorporado à } \\
\text { UFMG en 1962, teniendo el nombre cambiado para Escola de Música } \\
\text { da UFMG en 1972. } \\
\text { Localização: Belo Horizonte, MG } \\
\text { Administração: Pública, federal } \\
\text { Tipo de ingresso: ENEM (Exame Nacional do Ensino Médio - } \\
\text { vestibular nacional unificado) + HE } \\
\text { Vagas de bacharelado ofertadas por ano: } 76 \\
\text { Média de egressos por ano: } 47 \\
\text { Site: http://www2.musica.ufmg.br/ }\end{array}$ \\
\hline $\begin{array}{l}\text { IES: Universidade Federal do Rio de Janeiro } \\
\text { Sigla: UFRJ } \\
\text { Ano de fundação da IES: } 1920 \\
\text { Ano de fundação do curso: } 1848 \\
\text { Fundado como: Conservatório de Música. Transformado em Instituto } \\
\text { Nacional de Música em 1889. Incorporado à universidade em } 1923 \text {. } \\
\text { Em 1965, durante a ditadura militar, mudam-se os nomes para UFRJ e } \\
\text { Escola de Música da UFRJ. } \\
\text { Localização: Rio de Janeiro, RJ } \\
\text { Administração: Pública, federal } \\
\text { Tipo de ingresso: Vestibular unificado + HE } \\
\text { Vagas de bacharelado ofertadas por ano: } 104 \\
\text { Média de egressos por ano: } 38 \\
\text { Site: http://www.musica.ufrj.br/ }\end{array}$ & $\begin{array}{l}\text { IES: Universidade de São Paulo } \\
\text { Sigla: USP } \\
\text { Ano de fundação da IES: } 1934 \\
\text { Ano de fundação do curso: } 1971 \\
\text { Fundado como: Departamento de Música (CMU) da Escola de } \\
\text { Comunicação e Artes (ECA) } \\
\text { Localização: São Paulo, SP } \\
\text { Administração: Pública, estadual } \\
\text { Tipo de ingresso: Vestibular próprio + HE } \\
\text { Vagas de bacharelado ofertadas por ano: } 50 \\
\text { Média de egressos por ano: } 20 \\
\text { Site: http://www3.eca.usp.br/cmu }\end{array}$ \\
\hline
\end{tabular}

Quadro 2-Caracterização das IES

O tipo de administração de cada IES afeta diretamente as concepções curriculares e mesmo a autonomia institucional. UFMG e UFRJ são IFES (Instituições Federais de Ensino Superior), isto é, administradas pela União, respondendo diretamente ao CNE (Conselho Nacional de Educação) e ao MEC (Ministério da Educação), além de possuírem diretrizes internas provenientes de suas reitorias. Já USP e FAMES são instituições estaduais, administradas pelos governos locais das províncias, que respondem não somente às instâncias nacionais, mas também às regulamentações próprias de cada estado. Este dado é relevante uma vez que as instituições estaduais não passam, necessariamente, pelos mesmos processos de

Euridiana Silva Souza. 2019. (Educ)AÇÃO musical superior no sudeste do Brasil: Currículo como prática e possibilidades de ações do pensamento (de)colonialista. Action, Criticism, and Theory for Music Education 18 (3): 56-84. https://doi.org/10.22176/act18.3.56 
políticas da educação superior criadas diretamente para as IFES. Como exemplo destas políticas, o REUNI (Reestruturação e Ampliação das Universidades Federais), ampliou a oferta de vagas e possibilitou a criação de outros bacharelados, como musicoterapia e música popular. O programa também facilitou os processos de flexibilização curricular ${ }^{11}$.

A escolha por instituições federais e estaduais para o estudo comparado não se deu de forma prévia senão contingente, uma vez que o estado de São Paulo não possui IFES com cursos de música, e a UFES (Universidade Federal do Espírito Santo) tenha como oferta o curso de licenciatura em música e uma única habilitação de bacharelado. Tal condição, contudo, enriquece o processo de pesquisa em educação comparada.

Como diz Dominique Groux (1997), a comparação em educação tem um sentido. Ela nunca é gratuita. Quando rigorosamente efectuada, a leitura dos aspectos comuns e das diferenças relativas a uma problemática fornecem informações mais interessantes que as resultantes de uma leitura dessa mesma problemática num só contexto (Ferreira 2008, 125).

\begin{tabular}{|c|c|c|c|c|}
\hline $\begin{array}{c}\text { Habilitações dos } \\
\text { bacharelados }\end{array}$ & FAMES & UFMG & UFRJ & USP \\
\hline Canto & Canto & Canto & Canto & Canto e arte lírica \\
\hline Composiçao & $* * *$ & Composiçao & Composiçao & Composiçao \\
\hline Cordas dedilhadas & Violão, harpa & Violão, harpa & Violão, harpa & $\begin{array}{c}\text { Violão, viola brasileira, } \\
\text { harpa }\end{array}$ \\
\hline Cordas friccionadas & $\begin{array}{l}\text { Violino, viola, } \\
\text { violoncelo, } \\
\text { contrabaixo }\end{array}$ & $\begin{array}{l}\text { Violino, viola, } \\
\text { violoncelo, contrabaixo }\end{array}$ & $\begin{array}{l}\text { Violino, viola, } \\
\text { violoncelo, } \\
\text { contrabaixo }\end{array}$ & $\begin{array}{l}\text { Violino, viola, } \\
\text { violoncelo, } \\
\text { contrabaixo }\end{array}$ \\
\hline $\begin{array}{l}\text { Instrumentos de } \\
\text { sopro }\end{array}$ & $\begin{array}{l}\text { Flauta, oboé, } \\
\text { clarinete, fagote, } \\
\text { saxofone, trompa, } \\
\text { trompete, trombone, } \\
\text { tuba }\end{array}$ & $\begin{array}{l}\text { Flauta, oboé, } \\
\text { clarinete, fagote, } \\
\text { saxofone, trompa, } \\
\text { trompete, trombone }\end{array}$ & $\begin{array}{l}\text { Flauta, oboé, } \\
\text { clarinete, fagote, } \\
\text { saxofone, trompa, } \\
\text { trompete, } \\
\text { trombone, tuba }\end{array}$ & $\begin{array}{l}\text { Flauta, oboé, } \\
\text { clarinete, fagote, } \\
\text { trompa, trompete, } \\
\text { trombone, tuba }\end{array}$ \\
\hline Música popular & $* * *$ & Música popular & $* * *$ & $* * *$ \\
\hline Musicoterapia & $* * *$ & Musicoterapia & $* * *$ & $* * *$ \\
\hline Percussão & Percussão & Percussão & Percussão & Percussão \\
\hline Regência & $* * *$ & Regência & Orquestral, coral & Regência \\
\hline Teclados & Piano & Piano & Piano, órgão, cravo & Piano, órgão \\
\hline Total de habilitações & 18 & 21 & 23 & 20 \\
\hline
\end{tabular}

Quadro 3: Habilitação de bacharelados por IES

Nos parágrafos que seguem analiso trechos dos projetos pedagógicos das IES aqui apresentadas. A análise foca os conceitos de música e cultura que embasam a

Euridiana Silva Souza. 2019. (Educ)AÇÃO musical superior no sudeste do Brasil: Currículo como prática e possibilidades de ações do pensamento (de)colonialista. Action, Criticism, and Theory for Music Education 18 (3): 56-84. https://doi.org/10.22176/act18.3.56 
formação superior ofertada, elucidando o que cada instituição julga ser necessário e pertinente.

\section{Música}

Música, conceito-prática diversificada e amplamente discutida na história, aparece nos textos curriculares sob diferentes perspectivas, indo de objeto/produto/fazer presente na cultura e como cultura (Merriam 1964; Elliot 1995).

O texto da FAMES reconstrói a história da música ocidental, passando pela Grécia Antiga e chegando na colonização do Brasil. Menciona a enculturação dos índios pelos portugueses, sem mencionar a presença dos negros na constituição do próprio país. Ressaltando a música como "fazer dos especialistas", o texto revela o legado ocidentalista e eurocêntrico da sua concepção e prática musical. Embora seja um fazer socialmente localizado, a música ainda é colocada como construto em si. É percebida como imposição simbólica e não necessariamente construção relacional, uma vez que o outro-o indígena, o negro não mencionado, o primitivo-foi vencido por uma cultura "superior".

Com a chegada dos portugueses e dos jesuítas, foi introduzida a música religiosa e os ritmos da música portuguesa, dando-se, assim, início à aculturação dos índios aos moldes de Portugal. Tanto entre os povos primitivos do Brasil como de outras partes do mundo, a prática musical estava nas mãos de músicos especialistas capazes de transmitir os segredos de seu ofício para aqueles indivíduos a quem deveriam repassar o cargo. (FAMES 2011, 5)

Ainda que curto, o texto da USP ressalta a academia e o concerto que constituem base epistêmica de legitimação do fazer musical de tradição europeia.

Desde sua fundação, o curso de Graduação oferecido pelo CMU-ECA-USP tem se reportado ao aperfeiçoamento das habilidades criativas, técnicas, teóricas e de reflexão. É voltado a músicos que almejam direcionar sua carreira tanto às atividades de criação e concerto quanto ao campo acadêmico, que envolve a pesquisa, o ensino, a criação e a interpretação musical. (USP 2018)

Já o texto da UFRJ deixa explícito a manutenção da prática musical destacando a modernidade, que é o cerne para a constituição do pensamento colonialista. O texto ressalta o histórico e o contemporâneo dentro das perspectivas eurocêntricas. A música contemporânea de concerto, baseada nos movimentos de vanguarda do século XX, é bastante presente na análise das ementas das disciplinas oferecidas por esta instituição.

Euridiana Silva Souza. 2019. (Educ)AÇÃO musical superior no sudeste do Brasil: Currículo como prática e possibilidades de ações do pensamento (de)colonialista. Action, Criticism, and Theory for Music Education 18 (3): 56-84. https://doi.org/10.22176/act18.3.56 
Considera-se, neste projeto, uma estrutura que compreende um conjunto de disciplinas mais explicitamente fundamentadas nas tradições da teoria e da práxis da música da modernidade clássico-romântica como também disciplinas que abordam as tradições musicais brasileiras e a produção da cultura contemporânea. (UFRJ 2008, 7)

Já o texto da UFMG desenvolve uma visão expandida do fazer musical, retirandoo da dimensão dos especialistas e trazendo-o para a dimensão mais ampla do fazer humano, como produtor de cultura e não somente produto cultural. Assim coloca todos como músicos potenciais, "porque todos escutamos e de alguma forma somos sensíveis à música. E escutar é já fazer parte do evento musical” (UFMG 2011, s/p). Tal concepção de música potencializa a agência musical na sociedade. "Por meio das práticas musicais, estudam-se o comportamento humano, os fenômenos de movimentação de massas, os aparelhos de escuta e transmissão sonora, as religiões e sua dinâmica de comunicação, os mecanismos de pertencimento a grupos sociais" (s/p).

Analisando o conjunto dos documentos curriculares dos cursos de bacharelado, de forma coincidente (ou não), é possível inferir que o projeto curricular que apresenta a visão mais ocidentalizada e rígida de música, é o que apresenta menos mobilidade e abertura na formação dos estudantes. Na FAMES, para algumas habilitações de bacharelado não há, sequer, a possibilidade de matérias optativas, sendo a grade curricular totalmente fechada. Seguindo o mesmo raciocínio, o curso com concepção musical mais ampla também é o que permite uma formação de percurso expandido, permitindo ao estudante passar por outros cursos que enriqueçam sua prática profissional e sua formação geral.

\section{Cultura}

Considerando cultura como recurso, tal como propõe Yúdice (2013) ${ }^{12}$, alguns termos merecem destaque no campo da percepção da cultura aliada à construção curricular. Destaco do texto da UFMG os termos plural e dinâmico que qualificam o mercado cultural,

fruto de um processo histórico que vem paulatinamente alargando o escopo da formação musical superior, o curso de graduação da Escola de Música da UFMG não apenas se concentra no aperfeiçoamento técnico propriamente dito dos músicos, mas toma-o como ponto de partida a fim de também capacitar o egresso ... a ter uma visão global e crítica do fenômeno musical no mundo contemporâneo, dando-lhe condições de intervir com maior autonomia no processo

Euridiana Silva Souza. 2019. (Educ)AÇÃO musical superior no sudeste do Brasil: Currículo como prática e possibilidades de ações do pensamento (de)colonialista. Action, Criticism, and Theory for Music Education 18 (3): 56-84. https://doi.org/10.22176/act18.3.56 
extremamente plural e dinâmico que hoje caracteriza o mercado cultural. (UFMG 2011, s/p.)

Enquanto cultura (recurso) a música há muito está sujeitada à lógica do produtoconsumo, à lógica do capital, em suas diferentes caracterizações, seja simbólico ou mercantil, como bem desenvolveram Bourdieu (2008) e Yúdice (2013). Interessame, porém, destacar a consciência quanto à condição plural e processual na qual a música, enquanto mercado se desenvolve. Se existem condições plurais e dinâmicas, há possibilidade de diferença, de outros pensamentos e fazeres.

O texto da UFRJ ressalta possibilidade de um outro a partir das concepções que consideram a contemporaneidade múltipla, diversa e contraditória. $\mathrm{O}$ texto destaca o processo de globalização cultural que não trata apenas "de uma cultura de massa, já plenamente desenvolvida e consolidada desde meados do século XX, mas uma cultura da fragmentação, da desreferencialização e da entropia" (UFRJ 2008, 7). Neste cenário, justifica-se a formação do músico profissional transitando entre os conhecimentos técnicos-processuais e suas aplicações no mercado, considerando "o desenvolvimento da inteligência estética, a elaboração dos conceitos espaço-temporais, entre os quais tem destaque o ritmo, as novas tecnologias de difusão e de consumo, o desenvolvimento da criatividade, como instância crítica e criadora, entre outros aspectos" (7). Assim destaca-se uma formação ampliada que "dá ao futuro bacharel em Música os atributos necessários para a sua sustentação profissional, num mercado cada vez mais exigente de qualidade e amplitude técnica, podendo atingir o âmbito da cultura, da cidadania e da independência de pensamento" (7).

Fragmentação e falta de referência podem ser inferidas como quebra do pensamento homogêneo, o questionamento de uma legitimação única, seja de música, conhecimento, política, sociedade, cultura, ordem mundial.... Já entropia, que segundo as leis da termodinâmica, implica em desordem e ausência de regulação, também se relaciona diretamente com a "quantidade de macroestados possíveis" (Herscovici 2005), isto é, de diferentes organizações de um sistema. Assim, restame uma pergunta, ainda sem resposta: o destaque para estes termos na adjetivação de cultura, referem-se somente à uma constatação objetiva da diferença, ou trazem em si alguma nostalgia do pensamento homogeneizador? Há consciência da heterogeneidade social, pontuada pela entropia, mas há ação prática de valorização da diferença? Existe a possibilidade de diferentes confluências? Como os bacharéis se

Euridiana Silva Souza. 2019. (Educ)AÇÃO musical superior no sudeste do Brasil: Currículo como prática e possibilidades de ações do pensamento (de)colonialista. Action, Criticism, and Theory for Music Education 18 (3): 56-84. https://doi.org/10.22176/act18.3.56 
formam entre o peso do eurocentrismo colonialista e as múltiplas existências e sujeitos da nossa realidade?

\section{Uma formação ampla, crítica e reflexiva-possibilidades de ação (de)colonialista}

De acordo com a Resolução n.2 do Conselho Nacional de Educação que regulamenta os cursos de graduação em música no Brasil

[o] curso de graduação em Música deve ensejar, como perfil desejado do formando, capacitação para apropriação do pensamento reflexivo, da sensibilidade artística, da utilização das técnicas composicionais, do domínio dos conhecimentos relativos à manipulação composicional de meios acústicos, eletroacústicos e de outros meios experimentais, e da sensibilidade estética através do conhecimento de estilos, repertórios, obras e outras criações musicais, revelando habilidades e aptidões indispensáveis à atuação profissional na sociedade, nas dimensões artísticas, culturais, sociais, científicas, tecnológicas, inerentes à área da Música. (CNE 2004, $\mathrm{n}^{0}$ )

De forma bastante resumida, em consenso com a resolução posta, os textos curriculares buscam oferecer para os estudantes que o praticam, uma formação ampla, crítica e reflexiva. A FAMES tem como missão

promover a formação de músicos capazes de atuarem nos campos de sua formação musical como eficientes conhecedores e executores dos saberes teóricos e práticos inerentes a esse campo profissional e de contribuírem para a transformação social e melhoria da qualidade de vida das pessoas e da população. (FAMES 2011,7)

o curso de graduação da Escola de Música da UFMG não apenas se concentra no aperfeiçoamento técnico propriamente dito dos músicos, mas toma-o como ponto de partida a fim de também capacitar o egresso-por meio de uma formação artística e humanística abrangente que leva em conta o número inestimável de abordagens científicas para o estudo qualificado da música. (UFMG 2011, s/p.)

Desse modo, o oferecimento do Curso de Bacharelado em Música ... justifica-se pelo seu potencial em dar continuidade ao aprofundamento de metodologias de aperfeiçoamento musical e de preparação técnica do mundo contemporâneo. Com isso visa-se incorporar à formação dos alunos aspectos essenciais à sua formação e à construção de sua cidadania, tendo em vista crenças, intenções, significações, interpretações e avaliações que cercam a experiência musical em nossa contemporaneidade. (UFRJ 2008)

Partindo do que as IES do estudo definem para a formação do bacharel, e considerando as 2.400 horas mínimas que compõem a grade curricular de um bacharelado

Euridiana Silva Souza. 2019. (Educ)AÇÃO musical superior no sudeste do Brasil: Currículo como prática e possibilidades de ações do pensamento (de)colonialista. Action, Criticism, and Theory for Music Education 18 (3): 56-84. https://doi.org/10.22176/act18.3.56 
em música no Brasil, quais possibilidades as concepções de currículo oferecem para a efetivação e construção da uma formação ampla, crítica e reflexiva?

Retomo o princípio de que a lógica da colonialidade pode ser percebida como estrutura estruturante que define ideais, modelos e legitimações do dever-ser humano.

À dinâmica da colonialidade subjaz uma gama de tensões, conceitos, noções e práticas institucionalizadas.... A intensidade de tais tensões é alta, devido à linha traçada pela colonialidade entre sujeitos, saberes e ontologias dominantes e subalternas, e é, à sua vez, permeável e relativa. É frequente que como indivíduos que tenham sido colonizados mediante a socialização e educação nos convertamos em recolonizadores dos nossos semelhantes. (Shifres e Rosabal-Coto 2017, 86)

Ou como aponta Freire (2015), em sua Pedagogia do Oprimido-desenvolvida com e não para os homens-o sonho do oprimido, que não tomou consciência de sua opressão, é tornar-se opressor. Dentro desta perspectiva o autor destaca que

[o] grande problema está em como poderão os oprimidos, que "hospedam" o opressor em si, participar da elaboração, como seres duplos, inautênticos, da pedagogia de sua libertação. Somente na medida em que se descubram "hospedeiros" do opressor poderão contribuir para o partejamento de sua pedagogia libertadora. (Freire 2015, 41)

O caminho para a libertação não é dado. Ele é descoberto e construído, de forma individual e coletiva nos processos de tomada de consciência. Não se deixa de ser colonizado simplesmente porque a relação com a colônia não é mais historicamente constituída.

Posto isto, ao tomar as grades curriculares-disciplinas/carga horária-dos cursos aqui analisados, o peso da colonialidade se torna evidente, não só em termos de um repertório instrumental/vocal europeu, como também de uma concepção de percepção auditiva, métodos de análise e pensamento musical. A divisão pedagógica da seleção de conteúdos se organiza, geralmente, em núcleos. A quantidade percentual a ser cursada em cada núcleo, e sua condição de obrigatoriedade ou escolha, dizem também da opção de reprodução ou possibilidade de renovação da formação. E isso me faz questionar: o que seria uma formação ampla, reflexiva e crítica. $\mathrm{O}$ quadro abaixo oferece oportunidade para análise adicional.

Euridiana Silva Souza. 2019. (Educ)AÇÃO musical superior no sudeste do Brasil: Currículo como prática e possibilidades de ações do pensamento (de)colonialista. Action, Criticism, and Theory for Music Education 18 (3): 56-84. https://doi.org/10.22176/act18.3.56 


\begin{tabular}{|c|c|c|c|}
\hline Instituiç̧ão & Divisão de núcleos & $\begin{array}{l}\text { Carga horária } \\
\text { demandada }\end{array}$ & $\begin{array}{l}\text { Percentual com } \\
\text { relação ao total } \\
\text { de horas do curso }\end{array}$ \\
\hline \multirow{2}{*}{$\begin{array}{l}\text { FAMES } \\
\text { Carga horária do } \\
\text { curso: } \\
2460 \text { horas }\end{array}$} & $\begin{array}{l}\text { Núcleo básico obrigatório - conteúdos de formação geral (língua portuguesa, } \\
\text { história, sociologia e psicologia relacionados à música) }\end{array}$ & 390 horas & $15 \%$ \\
\hline & $\begin{array}{l}\text { Núcleo de conteúdos específicos } \\
\text { (análise, contraponto, instrumento, performance, percepção musical, etc.) } \\
\text { (Atividades geradoras de créditos complementam os demais } 11 \% \text { do curso) }\end{array}$ & 1800 horas & $74 \%$ \\
\hline \multirow{2}{*}{$\begin{array}{l}\text { USP } \\
\text { Carga horária do } \\
\text { curso: } \\
1785 \text { horas }\end{array}$} & $\begin{array}{l}\text { Carga obrigatória } \\
\text { (percepção, fundamentos de harmonia, história e música, instrumento, prática em } \\
\text { conjunto) }\end{array}$ & 1500 horas & $84 \%$ \\
\hline & $\begin{array}{l}\text { Carga optativa eletiva } \\
\text { (Disciplinas ofertadas pelos professores conforme demanda e escolhas pessoais) } \\
\text { não há a modalidade optativa livre, isto é, as optativas são oferecidas dentro do } \\
\text { próprio departamento de música. }\end{array}$ & 285 horas & $16 \%$ \\
\hline \multirow{3}{*}{$\begin{array}{l}\text { UFMG } \\
\text { Carga horária do } \\
\text { curso: } \\
\mathbf{2 4 0 0} \text { horas }\end{array}$} & $\begin{array}{l}\text { Carga obrigatória (percepção, fundamentos de harmonia, história e música, } \\
\text { instrumento, prática em conjunto) }\end{array}$ & 1320 horas & $55 \%$ \\
\hline & $\begin{array}{l}\text { Carga eletiva } \\
\text { Cursadas em outras habilitações dentro da própria escola de música. }\end{array}$ & 45 horas & $2 \%$ \\
\hline & $\begin{array}{l}\text { Carga optativa } \\
\text { (disciplinas optativas + formação complementar aberta + formação livre + atividades } \\
\text { geradoras de crédito) }\end{array}$ & 1035 horas & $45 \%$ \\
\hline \multirow{2}{*}{$\begin{array}{l}\text { UFRJ } \\
\text { Carga horária do } \\
\text { curso: } \\
2400 \text { horas }\end{array}$} & $\begin{array}{l}\text { Núcleo comum } \\
\text { (percepção, harmonia, história, instrumento, análise musical) }\end{array}$ & 1200 horas & $50 \%$ \\
\hline & $\begin{array}{l}\text { Núcleo profissional } \\
\text { (Disciplinas com conteúdos referentes às especificidades profissionais das diferentes } \\
\text { habilitações dos bacharelados) }\end{array}$ & 1200 horas & $50 \%$ \\
\hline
\end{tabular}

Quadro 4: Constituição e distribuição percentual das grades curriculares

Fonte: elaboração própria a partir das grades curriculares dos cursos

Embora seja da ordem do pensamento complexo, ouso usar os termos colonialista e decolonialista para classificar efetivações e possibilidades de formação das concepções curriculares. $\mathrm{O}$ termo colonial descreve a permanência de reprodução do ideal eurocêntrico. O termo decolonial, designa a construção de formações outras, distintas, não necessariamente previsíveis. Utilizo estes termos ainda por questionar o que é amplo. Seria a quantidade de conhecimento teórico-tecnicista do fazer musical? As muitas horas gastas na compreensão de processos e não de contextos sociais nos quais os processos são produzidos? E como se dão crítica e reflexão em processos previamente fechados, sem muitas capacidades de escolha de percurso por parte de quem está sendo formado?

Ao observar os dados referentes à FAMES, podemos classificar a concepção curricular como colonialista, baseada na reprodução, em um modelo a ser atingido sem possibilidade de alteração. USP e UFRJ transitam entre os termos, pendendo mais para a reprodução colonialista, uma vez que suas possibilidades de opção em formação não saem, ou pouco saem, do currículo da escola/departamento de música.

Euridiana Silva Souza. 2019. (Educ)AÇÃO musical superior no sudeste do Brasil: Currículo como prática e possibilidades de ações do pensamento (de)colonialista. Action, Criticism, and Theory for Music Education 18 (3): 56-84. https://doi.org/10.22176/act18.3.56 
Já o currículo da UFMG permite, pela prática efetiva da flexibilização curricular, uma possibilidade de ação/pensamento decolonial. Não falo em termos absolutos, e nem assumo que o bacharelado em música da UFMG atue segundo o pensamento decolonial. O texto e a estrutura curricular possibilitam heterogeneidade, aliados à expansão universitária do REUNI. Através do REUNI outros tiveram acesso ao ensino superior-músicos populares, de comunidades subalternas, com outras perspectivas do fazer musical na sociedade. Estes fatos permitem tal inferência. Ressalto que, para além do currículo de um curso, a própria concepção curricular desta instituição acentua as possibilidades de ações decoloniais, através dos chamados processos de formação transversal, dentre os quais localiza-se o encontro de saberes e mestres tradicionais.

O Encontro dos Saberes, que acontece em algumas universidades brasileiras e espalhadas pelas América Latina, é uma "aposta política", que tem se tornado efetiva, para

decolonizar os conhecimentos universitários eurocêntricos com a inclusão de saberes indígenas, afros e de outras comunidades tradicionais da região, considerando-os como saberes válidos que devem ser ensinados em igualdade de condições.... O Encontro de Saberes tem como proposta retomar, também para os docentes universitários, submetidos à lógica capitalista do produtivismo e da despersonalização, o lugar dos mestres ou sabedores, e com ele reescrever a dimensão dos saberes na academia, com condições para dialogar com as formas tradicionais sem que nenhuma seja reduzida à dimensão exclusiva de conhecimentos científicos, quantificáveis e mensuráveis. (Carvalho e Flórez-Flórez 2014, 133)

O fato de esta política estar presente como formação transversal na UFMG não é garantia de aderência imediata por parte dos estudantes, mas é uma possibilidade de formação.

\section{O currículo em (educ)ação musical: possibilidades e sujeitos da prá- tica-à guisa de conclusão}

Analisei de forma teórica, o currículo como prática e inferi sobre suas possibilidades de ampliação ou reprodução epistêmica, ou seja, da manutenção do colonialismo ou da abertura para a possibilidade de um pensamento decolonial. Assim, volto aos sujeitos da prática. De quase nada me serve esse pensamento teórico se retiro dele os sujeitos que efetivamente constroem esta prática. A abertura para uma reflexão de cunho decolonial não garante esta reflexão. Há que se ter um

Euridiana Silva Souza. 2019. (Educ)AÇÃO musical superior no sudeste do Brasil: Currículo como prática e possibilidades de ações do pensamento (de)colonialista. Action, Criticism, and Theory for Music Education 18 (3): 56-84. https://doi.org/10.22176/act18.3.56 
sujeito, seja ele professor ou aluno, consciente, problematizador que desperte a discussão, a crítica e a reflexão, que amplie o processo de formação. Há que se colocar o currículo em ação, assumi-lo e favorecer a mudança ou a permanência. Afinal,

quanto mais me assumo como estou e sendo e percebo a ou as razões de ser, de porque estou sendo assim, mais me torno capaz de mudar, de promover-me, no caso de uma curiosidade ingênua para uma curiosidade epistemológica. Não é possível a assunção que o sujeito faz de si numa certa forma de estar sendo sem a disponibilidade para mudar. Para mudar e de cujo processo se faz necessariamente sujeito também. (Freire 1996, 44)

O currículo precisa de uma assunção e mudança de pensamento que superem o efeito da colonização epistêmica que reduz a complexidade dos saberes e conhecimentos e dimensões únicas, disciplinares, disciplinarizadas e despersonalizadas (Carvalho e Flórez-Flórez 2014, 133).

Posto isso, sugiro algumas reflexões para que as possibilidades de um efetivo giro decolonial na universidade se concretizem.

O currículo, embora seleção oficial de diferentes instâncias político-administrativas da educação superior, é prática e se faz na prática. É papel do docente universitário despertar a curiosidade no aluno sobre os possíveis caminhos a serem traçados em uma formação superior. É papel do aluno conscientizar-se sobre o lugar que ele ocupa enquanto sujeito da educação no sistema superior. Afinal, "não há docência sem discência" (Freire 1996, 23), e vice-versa.

Parece uma reflexão simplória, no entanto, de que adianta a política curricular permitir caminhos e formações outras, se os sujeitos não a colocam em prática? Ou, como transcender a reprodutibilidade de valores e práticas da modernidade europeia, se esta é única visão praticada por discentes e docentes? Como libertar-se sem a tomada de consciência?

Volto aos sujeitos, egressos destes cursos que, em questionários e entrevistas sobre a construção de suas identidades profissionais, relataram não só a rigidez curricular, como fator desmotivante na formação, mas pontuaram:

1) Os padrões eurocêntricos, o não diálogo com a realidade e a disciplinarização como quebra de expectativas em suas formações profissionais.

Acredito que o ensino de música ainda é muito voltado para os padrões europeus, com seus métodos, costumes, práticas e repertórios. O mercado de trabalho no Brasil vai muito além da música de concerto europeia e acabamos não nos preparando para esta realidade (Tim, bacharel em clarineta, UFRJ).

Euridiana Silva Souza. 2019. (Educ)AÇÃO musical superior no sudeste do Brasil: Currículo como prática e possibilidades de ações do pensamento (de)colonialista. Action, Criticism, and Theory for Music Education 18 (3): 56-84. https://doi.org/10.22176/act18.3.56 
faltava diálogo entre as disciplinas e os professores. Nós do bacharelado não éramos treinados para um mercado realista (Rodman, bacharel em flauta, UFMG).

O curso é basicamente estruturado na prática de um repertório para piano solo como se você fosse solista (Fran, bacharel em Música Popular, UFMG).

Gostaria que as matérias se relacionassem mais umas com as outras (Aurora, bacharel em piano, UFRJ).

2) A liberdade da flexibilização curricular como algo intimidador.

Achei o currículo muito livre. Isso é bom em parte, mas o meu curso acabou ficando um pouco sem foco. Se, por uma lado, a liberdade na grade curricular é extremamente eficaz porque o graduando pode adequar o curso conforme as suas necessidades ou desejos profissionais, por outro essa liberdade pode ser muito ruim para o graduando que não tem uma ideia muito boa da demanda do mercado profissional e seu currículo fica deficiente de matérias essenciais para uma formação que seja de fato efetiva (Rita, bacharel em violino, UFMG.

Estas pontuações vão de encontro aos desafios da docência do ensino superior apontadas por Masetto (2015), especialmente no que tange à construção e socialização de um conhecimento interdisciplinar ${ }^{13}$, e de uma atitude de parceria com seus pares (demais docentes) e alunos. $\mathrm{O}$ autor localiza na mudança da postura do professor a resposta para este desafio. Faz-se necessário

[u]m professor mediador que aprenda a trabalhar em equipe com os alunos e com seus pares na construção da docência de uma AULA UNIVERSITÁRIA entendida como o espaço-tempo no qual os PERSONAGENS agem e interagem, e nesse intercurso de ações CONSTROEM um processo de aprendizagem e de FORMAÇÃO PROFISSIONAL CIDADÃ. (Masetto 2015, grifos do autor)

Considerando a proposta de uma formação ampla, crítica e reflexiva, e compreendendo a aula universitária como quaisquer espaço-tempo em que experiências se tornem aprendizados conscientes para uma formação profissional cidadã, o currículo como prática pode ser visto como um lócus de profilaxia social.

A profilaxia social é uma ação preventiva para o bem comum e individual. Para além de uma metáfora tomada das ciências da saúde, como conjunto de ações tomadas para preservação e manutenção da saúde e que atua para a prevenção contra malefícios. A profilaxia, quando posta em ação na sociedade, encontra lugar nos processos educacionais como espaços de informação e (trans)formação dos seres humanos. Aqui, considero a possibilidade de sistemas de educação que desenvolvem formações amplas, transcendendo conteúdos e técnicas, e podendo refletir valores mais humanos e fadados ao inacabamento dos seres (Freire 1996).

Euridiana Silva Souza. 2019. (Educ)AÇÃO musical superior no sudeste do Brasil: Currículo como prática e possibilidades de ações do pensamento (de)colonialista. Action, Criticism, and Theory for Music Education 18 (3): 56-84. https://doi.org/10.22176/act18.3.56 
Localizar na (educ)ação musical superior, e nos formatos de seus currículos as possibilidades de uma ação profilática, requer a compreensão da educação musical como "profilaxia social" (Czanok 2013). Este pensamento considera a educação musical em seu estado híbrido: educação enquanto projeto político e música enquanto relação. Uma educação musical que considera a alteridade, a diferença e que busca uma equidade nos processos de transmissão de conhecimentos e saberes, de formação e inserção profissional dos músicos no mercado.

A educação, como movimento dialético no e para o desenvolvimento humano, requer que pensemos além das duras realidades, às vezes, impostas às escolas $\mathrm{e}$ naturalizadas por aqueles e aquelas que não acreditam na educação como força geradora de transformações sociais e culturais capazes de provocar mudanças. (Nörberg e Foster 2016, 190)

Sugiro tal profilaxia a partir da formação superior por acreditar que profissionais bem formados conseguem romper ou reinventar ciclos que têm se tornado viciosos no mercado de trabalho, no sistema escolar e no estar e perceber-se no mundo. A flexibilização curricular, a mudança de postura de docentes e discentes, o trânsito entre os saberes e os conhecimentos marcam as possibilidades dos giros de pensamento que rompem com os silenciamentos que história colonialista carrega.

\section{Sobre a autora}

Euridiana Silva Souza, PhD em Educação Musical, Mestre em Estudo das Práticas Musicais e Bacharel em Piano pela Universidade Federal de Minas de Gerais. Desenvolve pesquisas sobre formação de identidade profissional de músicos e processos de formação na educação musical superior. Foi professora dos cursos de licenciatura em Música na Universidade de Brasília, pianista e professora na Orquestra de Câmara do Sesi e atualmente leciona e coordena os cursos de Música da Fábrica de Artes em Belo Horizonte. Atua como pianista dos grupos de câmara DuoAlismo (piano e viola) e TripTango (piano, oboé e viola).

\section{Referências}

Anacoana, Paula 2012. Eu sou favela - coletivo. Anacoana Editions.

Antunes, Vinícius Volcof. 2016. Expansão e democratização universitária: A implementação do REUNI na Universidade Federal do Rio de Janeiro. Revista Habitus 14 (1): 91-9.

Euridiana Silva Souza. 2019. (Educ)AÇÃO musical superior no sudeste do Brasil: Currículo como prática e possibilidades de ações do pensamento (de)colonialista. Action, Criticism, and Theory for Music Education 18 (3): 56-84. https://doi.org/10.22176/act18.3.56 
Aredes, Rubens. 2015. A bimusicalidade na relação entre universidade e favela. Reflexões sobre uma experiência etnomusicológica em uma favela brasileira. Post-ip ?15 Post-in-progress: Revista do Fórum Internacional de Etudos em Música e Dança 3: 239-46.

Arroyo, Margarete, Elizabeth Lucas, Marilia Stein, e Luciana Prass. 2003. Entre congadeiros e sambistas: Etnopedagogias musicais em contextos populares de tradição afro-brasileira. Revista da Fundarte 3 (5): 4-20.

Ballestrin, Luciana. 2013. América Latina e o giro decolonial. Revista Brasileira de Ciência Política 11: 89-117.

Bennett, Dawn E. 2008. Understanding the classical music profession. London: Routledge.

Borges, Maria, e Orlando Aquino. 2012. Educação superior no Brasil e as políticas de expansão de vagas do REUNI: Avanços e controvérsias. Educação: Teoria e Prática 22 (39): 117-38.

Bourdieu, Pierre. 2008. A distinção: crítica social do julgamento. São Paulo: Edusp.

Catani, Afrânio, João de Oliveira, e Luiz Dourado. 2001. Política educacional, mudanças no mundo do trabalho e reforma curricular dos cursos de graduação no Brasil. Educação \& Sociedade 22 (75): 67-83.

Carvalho, José Jorge, e Juliana Flórez-Flórez. 2014. Encuentro de saberes: Proyecto para decolonizar el conocimiento universitario eurocentrico. Nómadas 41: 131-47.

Caznok, Yara. 2013. A educação musical como profilaxia social. Montevideo: FLADEM.

CNE-Conselho Nacional de Educação / Ministério da Educação. 2004. Resolução $n^{o_{2}}$. Brasília, MEC. Disponível em: portal.mec.gov.br/cne/arquivos/pdf/po4.pdf.

Coelho, Maria de Lourdes. 2014. O programa REUNI na UFMG: Contexto, adesão, implantação, criação do Giz e suas ações formativas. Revista Docência do Ensino Superior 4: 3-46.

Dempsey, Genevieve. 2017. The acoustics of justice: Music and myth in Afro-Brazilian congado. Yale Journal of Music \& Religion 3 (2): 1-25.

Euridiana Silva Souza. 2019. (Educ)AÇÃO musical superior no sudeste do Brasil: Currículo como prática e possibilidades de ações do pensamento (de)colonialista. Action, Criticism, and Theory for Music Education 18 (3): 56-84. https://doi.org/10.22176/act18.3.56 
Elliot, David. 1995. Music matters: A new philosophy of music education. Oxford: Oxford University Press.

Faculdade de Música do Espírito Santo-FAMES. 2011. Projeto pedagógico do curso de bacharelado em música. Vitória.

Ferreira, António Gomes. 2008. O sentido da educação comparada: Uma compreensão sobre a construção de uma identidade. Educação 31 (2): 124-38.

Fragoso, Daisy. 2018. Interlocuções entre a etnomusicologia e a educação musical. Revista Música 18 (1): 143-69.

Freire, Paulo. 2015. Pedagogia do oprimido. 51a ed. Rio de Janeiro: Paz e Terra.

Freire, Paulo. 1996. Pedagogia da autonomia: Saberes necessários à prática educativa. 23a ed. São Paulo: Paz e Terra.

Garcia, Walter. 2013. Rap. In Dimensões políticas da justiça, editado por Leonardo Avritizer, Newton Bignotto, Fernando Filgueiras, Juarez Guimarães, e Heloísa Starling, 637-46/ Rio de Janeiro: Civilização Brasileira.

Green, Lucy. 2014. Music education as critical theory and practice-Selected essays. Surrey: Ashgate.

Grosfoguel, Ramón. 2013. Desenvolvimentismo, modernidade e teoria da dependência na América Latina. Realis 3 (2): 26-55.

Hair Jr., Joseph, William Black, Barry Babbin, Rolph Anderson, e Ronald Tatham. 2009. Análise multivariada de dados. Porto Alegre, Bookman.

Herscovici, Alain. 2005. Historicidade, entropia e não linearidade: Algumas aplicações possíveis na ciência econômica. Revista de Economia Política 25 (3): 277-94.

Heusi, Alina Cristina da Silva. 2014. Determinação do cálculo de custo por vaga e matrícula efetiva em universidade pública: Um estudo de caso no Centro de Artes da Universidade do Estado de Santa Catarina. Dissertação (Mestrado). Programa de Pós-Graduação em Administração, CCAS. Florianópolis: UDES.

Kummu, Matti, e Olli Varis. 2011. The world by latitudes: A global analysis of human population, development level and environment across the North-South axis over the past half century. Applied Geography 31 (2): 495-507.

Lander, Edgardo, ed. 2005. A colonialidade do saber: Eurocentrismo e ciências sociais. Perspectivas latinoamericanas. Buenos Aires: CLACSO.

Euridiana Silva Souza. 2019. (Educ)AÇÃO musical superior no sudeste do Brasil: Currículo como prática e possibilidades de ações do pensamento (de)colonialista. Action, Criticism, and Theory for Music Education 18 (3): 56-84. https://doi.org/10.22176/act18.3.56 
Léda, Denise, e Deise Mancebo. 2009. REUNI: heteronomia e precarização da universidade e do trabalho docente. Educação e Realidade 34 (1): 49-64.

Leite, Lúcia Helena Alvarez. 2010. Com um pé na aldeia e um pé no mundo: Avanços, dificuldades e desafios na construção das escolas indígenas públicas e diferenciadas no Brasil. Currículo sem fronteiras 10(1): 195-212.

Lima, Edileusa Esteves, e Lucília Regina de Souza Machado. 2016. REUNI e Expansão Universitária na UFMG de 2008 a 2012. Educação \& Realidade 41 (2): 383-406.

Lopes, Alice Casimiro, e Silvia Braña Lopéz. 2010. A performatividade nas políticas de currículo: O caso do Enem. Educação em Revista. 26 (1): 89-110.

Louro, Ana Lúcia, e Jusamara Souza. 1999. Reformas Curriculares dos cursos superiores em música e formação de professores de instrumento. XII Encontro da ANPPOM, Salvador. https://antigo.anppom.com.br/anais/anaiscongresso_anppom_1999/ANPPOM\%2099/PAINEIS/LOURO.PDF

Louro, Ana Lúcia. 1998. Formação do professor de instrumento: Grades curriculares dos cursos de bacharelado Fundamentos da Educação Musical. Revista da ABEM 4: 106-9.

Louro, Ana Lúcia. 1997. Disciplinas pedagógicas no curso de bacharelado em Música. Expressão 1 (1-2): 17-20.

Lucas, Glaura. 2002. Musical rituals of Afro-Brazilian religious groups within the ceremonies of congado. Yearbook for Traditional Music 34: 115-27.

Luedy, Eduardo. 2009. Analfabetos musicais, processos seletivos e a legitimação do conhecimento em música: Pressupostos e implicações pedagógicas em duas instâncias discursivas da área de música. Revista da ABEM 22: 49-55.

Masetto, Marco Tarciso. 2015. Desafios para a docência no ensino superior na contemporaneidade. In Didática e prática de ensino: Diálogos sobre a escola e formação de professores e a sociedade. 1a ed., editado por M. M. D. Cavalcante, J. A. J. Sales, I. M. S. Farias, e M. S. L Lima, 779-95/ Fortaleza: EdUECE.

Merriam, Alan P. 1964. The anthropology of music. Illinois: Northwestern University Press.

Euridiana Silva Souza. 2019. (Educ)AÇÃO musical superior no sudeste do Brasil: Currículo como prática e possibilidades de ações do pensamento (de)colonialista. Action, Criticism, and Theory for Music Education 18 (3): 56-84. https://doi.org/10.22176/act18.3.56 
Miglievich-Ribeiro, Adelia. 2014. Por uma razão decolonial: Desafios ético-político-epistemológicos à cosmovisão moderna. Civitas-Revista de Ciências Sociais 14 (1): 66-80.

Mignolo, Walter D. 2003. Histórias globais, projetos locais: Colonialidade, saberes subalternos e pensamento liminar. Belo Horizonte: Ed. UFMG.

Moraes, Mariana Ramos de. 2018. De religião a cultura, de cultura a religião: Travessias Afro-religiosas no espaço público. Belo Horizonte: PUC Minas.

Nettl, Bruno. 2010. Music education and ethonomusicology: A (usually) harmonious relationship. Paper presented at the 29th World Conference of International Society for Music Education, Beijing, China.

Nörberg, Nara Eunice, e Mari Margarete dos Santos Forster. 2016. Ensino superior: As competências docentes para ensinar no mundo contemporâneo. Revista de Docência do Ensino Superior 6 (1): 187-210.

Palombini, Carlos. 2013. Funk proibido. In Dimensões políticas da justiça, editado por Leonardo Avritizer, Newton Bignotto, Fernando Filgueiras, Juarez Guimarães, e Heloísa Starling, 647-56/ Rio de Janeiro: Civilização Brasileira.

Pereira, Marcus Vinícius Medeiros. 2013. O ensino superior e as licenciaturas em música: Um retrato do habitus conservatorial nos documentos curriculares. Campo Grande: Ed. UFMS.

Porto-Gonçalves, Carlos Walter. 2005. Apresentação da edição em português. In $A$ colonialidade do saber: Eurocentrismo e ciências sociais. Perspectivas latinoamericanas, editado por Edgardo Lander, 3-5 /Buenos Aires: CLACSO.

Quijano, Aníbal. 2005. Colonialidade do poder, eurocentrismo e América Latina. In A colonialidade do saber: Eurocentrismo e ciências sociais. Perspectivas latinoamericanas, editado por Edgardo Lander, 107-130/ Buenos Aires: CLACSO.

Reinert, Clio. 2005. Metodologia para apuração de custos nas IFES brasileiras. Dissertação (Mestrado). Programa de Pós-Graduação em Administração. Florianópolis: Universidade Federal de Santa Catarina.

Sacristán, José Gimeno. 2000. O currículo: Uma reflexão sobre a prática. 3a ed. Porto Alegre: ArtMed.

Sánchez Vásquez, Adolfo. 2011. Filosofia da práxis. 2a ed. São Paulo: Expressão Popular.

Euridiana Silva Souza. 2019. (Educ)AÇÃO musical superior no sudeste do Brasil: Currículo como prática e possibilidades de ações do pensamento (de)colonialista. Action, Criticism, and Theory for Music Education 18 (3): 56-84. https://doi.org/10.22176/act18.3.56 
Santos, Boaventura de Sousa. 2007. Para além do pensamento abissal - Das linhas globais a uma ecologia de saberes. Novos Estudos 79: 71-94.

Santos, Boaventura de Sousa. 2004. A Universidade no século XXI. São Paulo: Cortez Editora.

Shifres, Favio, e Daniel H. Gonnet. 2015. Problematizando la herencia colonial en la educación musical. Epistemus 3 (2): 51-67.

Shifres, Favio, e Guillermo Rosabal-Coto. 2017. Hacia una educación musical decolonial en y desde América Latina. RIEM 5: 85-90.

Tugny, Rosângela Pereira de. 2015. Agência dos objetos sonoros. Per Musi 31: $322-44$.

Universidade Federal de Minas Gerais - UFMG. 2011. Projeto Pedagógico. Belo Horizonte.

Universidade Federal do Rio de Janeiro - UFRJ. 2008. Curso de bacharelado em música-projeto pedagógico. Rio de Janeiro.

Universidade de São Paulo - USP. 2017. Bacharelado em Música. São Paulo.

Viveiros de Castro, Eduardo. 2014. A inconstância da alma selvagem. Brasil: Cosac Naify.

Woodford, Paul. G. 2002. The social construction of music teacher identity in undergraduate music education majors. In The new handbook of research on music teaching and learning, editado por Richard Colwell e Carol Richardson, 675-94/ Nova York: Oxford University Press.

Yúdice, George. 2013. A conveniência da cultura: usos da cultura na era global. Belo Horizonte: Ed. UFMG.

\section{Notes}

${ }^{1}$ Ao adjetivar e localizar um habitus conservatorial nos documentos curriculares das licenciaturas em música, Pereira (2013) propõem não necessariamente uma denúncia, uma demonização do sistema conservatorial em si, mas a tomada de consciência de que muitas mudanças curriculares se deram de forma cosmética. A tomada de consciência desse habitus é um passo para seu processo de transformação, afim de que esta concepção eurocêntrica não seja tomada como único destino, mas como uma possibilidade dentro das muitas possibilidades que existem nos

Euridiana Silva Souza. 2019. (Educ)AÇÃO musical superior no sudeste do Brasil: Currículo como prática e possibilidades de ações do pensamento (de)colonialista. Action, Criticism, and Theory for Music Education 18 (3): 56-84. https://doi.org/10.22176/act18.3.56 
nossos fazeres musicais. Sobre os impactos do modelo conservatorial como herança colonialista, ver Shifres e Gonnet (2015).

${ }^{2}$ Os parênteses em (de)colonialismo sugerem a possibilidade de ser tanto um como outro. Faço esta opção de escrita para evitar a repetição dos termos colonialismo/decolonialismo a todo momento.

3 As análises do censo demográfico e econômico do Brasil podem ser consultadas diretamente no site do Instituto Brasileiro de Geografia e Estatística: https://ww2.ibge.gov.br/home/default.php.

4 Os cursos superiores em música são apresentados nas modalidades bacharelado-em instrumentos, regência, composição, musicoterapia, música popular-ou licenciatura-com habilitação em instrumentos ou educação musical. Importa-nos salientar a diferença entre os termos aplicados na Educação Superior nos demais países da América Latina. Os cursos equivalentes aos bacharelados brasileiros são denominados licenciaturas, e os equivalentes às licenciaturas brasileiras são denominados pedagogias.

5 No Brasil há cerca de 275 etnias indígenas, segundo dado da FUNAI (Fundação Nacional do Índio). O censo nacional realizado pelo IBGE (Instituto Brasileiro de Geografia e Estatística), apresentou um total de 817.963 indígenas no país, dos quais 97.960 encontram-se na região Sudeste (IBGE 2010). Na última década é possível acompanhar uma maior inserção das culturas indígenas nos espaços acadêmicos, como estudantes de programas de formação de educadores indígenas, outros cursos regulares, ou como mestres de saberes tradicionais. As barreiras de comunicação pelas diferenças linguísticas e culturais se tornam mais maleáveis neste espaço baseadas no pensamento decolonial. Ver Carvalho e Flórez-Flórez (2014); Leite (2010).

${ }^{6}$ Os quilombos, historicamente, foram redutos de abrigo e resistência durante o período escravocrata no Brasil. Muitas comunidades se constituíram a partir destes redutos, perpetuando suas tradições de matrizes africanas e ressignificando tradições, especialmente do catolicismo popular. Em 1988, com o processo de redemocratização do Brasil, estas comunidades passaram a ter alguma visibilidade dentro das políticas, e desde então vêm lutando por seus direitos. A Instrução Normativa n.16, promulgada pelo Governo Federal em 2004, apresenta: "Consideramse remanescentes das comunidades dos quilombos os grupos étnico-racionais, segundo critério de auto atribuição, com trajetória histórica próprias, dotados de relações territoriais específicas, com presunção de ancestralidade negra relacionada com a resistência à opressão histórica sofrida. Considerem-se terras ocupadas por remanescentes das comunidades de quilombos toda a terra utilizada para a garantia de sua reprodução física, social, econômica e cultural, bem como as áreas

Euridiana Silva Souza. 2019. (Educ)AÇÃO musical superior no sudeste do Brasil: Currículo como prática e possibilidades de ações do pensamento (de)colonialista. Action, Criticism, and Theory for Music Education 18 (3): 56-84. https://doi.org/10.22176/act18.3.56 
detentoras de recursos ambientes necessários à preservação dos seus costumes, tradições, cultura e lazer, englobando espaços de moradia, e, inclusive espaços destinados a cultos religiosos e os sítios que contenham reminiscências históricas dos antigos quilombos."

7 A peculiaridade do curso ganha destaque com as aulas individuais de instrumento/canto. Essa particularidade eleva os valores do 'custo vaga' e 'custo aluno' ou 'custo vaga efetiva'. A discussão destes valores, que ocorre na esfera da administração universitária e da administração pública, demanda a compreensão de sistemas de custeio e rateio de verbas, que, como aponta Heusi (2014) não são homogêneos, nem definidos segundo uma mesma lógica. Os cálculos variáveis do custo-aluno incorporam: recursos disponíveis; custo total das atividades de nível universitário (graduação e pós-graduação strictu senso); custo da administração e formação docente; custo das atividades fim (ensino, pesquisa e extensão); custo do médio da hora de ensino; custo de vagas ociosas e retenções do tempo previsto de formação; entre outros (Reinert, 2005).

8 Embora o total de IES que ofereça Bacharelados seja 52, apenas 51 estão apontadas no mapa (figura 1), uma vez que uma das instituições oferece o curso em modalidade de Ensino à Distância (EaD), tornando indiferente a localização física da IES.

9 Esta tomada de opção metodológica, de trabalhar com materiais disponíveis nos sites, justifica-se por evidenciar um material ao qual todos os estudantes, aspirantes e egressos tenham acesso. Embora os sites possam ser modificados, a coleta de dados sobre os documentos foi feita de forma sistemática, acompanhando todas as atualizações de conteúdo.

${ }^{10}$ Para a compreensão do vestibular unificado - ENEM (Exame Nacional do Ensino Médio), ver Lopes e López (2010). Para reflexões sobre a prova de Habilidades Específicas (HE) para ingresso no curso superior de música, ver Luedy (2009).

${ }^{11}$ Análises sobre a implementação do REUNI na UFMG podem ser consultadas em Lima e Machado (2012); Coelho (2014). Sobre a ilusão de democratização e implementação do REUNI na UFRJ, ver Antunes (2016). Sobre as relações de implementação do REUNI e precarização do trabalho docente no ensino superior, ver Léda e Mancebo (2009). Sobre avanços e controvérsias do REUNI, ver Borges e Aquino (2001). Para relatórios oficiais do MEC sobre o REUNI, ver http://reuni.mec.gov.br.

12 "A cultura como recurso é muito mais do que uma mercadoria; ela é o eixo de uma nova estrutura epistêmica na qual a ideologia e aquilo que Foucault denominou sociedade disciplinar (isto é, a imposição de normas a instituições como a

Euridiana Silva Souza. 2019. (Educ)AÇÃO musical superior no sudeste do Brasil: Currículo como prática e possibilidades de ações do pensamento (de)colonialista. Action, Criticism, and Theory for Music Education 18 (3): 56-84. https://doi.org/10.22176/act18.3.56 
educacional, a médica, a psiquiátrica etc.) são absorvidos por uma racionalidade econômica ou ecológica, de tal forma que o gerenciamento, a conservação, o acesso, a distribuição e o investimento-em "cultura" e seus resultados-tornamse prioritários (Yúdice 2013,13).

${ }^{13}$ Quiçá, uma transdisciplinaridade ou ainda uma indisciplinaridade, como sugere Viveiros de Castro (2002).

Euridiana Silva Souza. 2019. (Educ)AÇÃO musical superior no sudeste do Brasil: Currículo como prática e possibilidades de ações do pensamento (de)colonialista. Action, Criticism, and Theory for Music Education 18 (3): 56-84. https://doi.org/10.22176/act18.3.56 